\title{
Solidification of Cs-137-Bearing Radioactive Waste in Cenosphere-Based Mineral-Like Hosts for Long-Term Disposal in Granithoids
}

\author{
Nataly G. Vasilieva* and Tatiana A. Vereshchagina \\ Institute of Chemistry and Chemical Technology \\ 50/24 Akademgorodok, Krasnoyarsk, 660036, Russia
}

Received 22.03.2015, received in revised form 20.05.2015, accepted 14.07.2015

Theoretical and practical possibility to stabilize Cs-137(Na)-bearing liquid radioactive waste in mineral-like forms which are geochemically compatible with granithoids in its long-term disposal was demonstrated. Perforated cenospheres $\left(\mathrm{SiO}_{2} / \mathrm{Al}_{2} \mathrm{O}_{3}=3.4\right)$ of fly ash generated from combustion of kuznetskii coal was used as an aluminosilicate precursor. It was established that solidification of Cs-bearing solutions at 750-1100 ${ }^{\circ} \mathrm{C}$ via the proposed route resulted in glass-crystalline compounds incorporating 53-79 wt. \% pollucite with the Cs leaching rate being by 2-3 order of magnitude lower than the standard parameter accepted in Russia for solidified high level waste.

Keywords: cenospheres, radioactive waste, mineral-like hosts, pollucite.

\section{Отверждение Cs-137-содержащих радиоактивных отходов в минералоподобных матрицах на основе ценосфер для долговременного захоронения в гранитоидах}

Н.Г. Васильева, Т.А. Верещагина Институт химии и химической технологии СО РАН Россия, 660036, Красноярск, Академгородок, 50/24

Продемонстрированы теоретическая и практическая возможности отверждения Cs-137(Na)содержащих жидких радиоактивных отходов в минералоподобных формах, геохимически совместимых с гранитоидами при долговременном захоронении, с использованием в качестве

(c) Siberian Federal University. All rights reserved

* Corresponding author E-mail address: vng2702@gmail.com 
алюмосиликатного прекурсора перфорированных изеносфер $\left(\mathrm{SiO}_{2} / \mathrm{Al}_{2} \mathrm{O}_{3}=3,4\right)$, выделенных из летучих зол от сжигания углей Кузнецкого бассейна. Установлено, что отверждение по предложенной схеме Cs-содержащих растворов позволяет получить при температуре 750-1100 ${ }^{\circ} \mathrm{C}$ стеклокристаллические компаунды, включающие 53-79 мас. \% фазы поллуцита и характеризующиеся скоростью выщцелачивания цезия на 2-3 порядка ниже нормативного показателя, установленного в России для отвержденных высокоактивных отходов.

Ключевые слова: ценосферы, радиоактивные отходы, минералоподобные матриць, поллуцитт.

\section{Введение}

Использование ядерной энергетики и реализация военных программ по производству оружейного плутония привели к накоплению в мире большого количества жидких радиоактивных отходов (ЖРО) различного уровня активности, представляющих опасность для человека и окружающей среды как источников ионизирующих излучений. К проблемным категориям радиоактивных отходов относят жидкие средне- и высокоактивные отходы (САО и ВАО), содержащие тепловыделяющие радиоизотопы ${ }^{137} \mathrm{Cs}$ и ${ }^{90} \mathrm{Sr}[1]$, которые образуются в результате переработки отработавшего ядерного топлива (фракция Cs-Sr) при эксплуатации атомных электростанций (регенерационные растворы с высокой концентрацией солей натрия, кубовые остатки) [2], а также в случае тяжелых аварийных ситуаций на АЭС, подобных аварии на АЭС «Фукусима-1» в Японии [3]. Высокое тепловыделение радионуклидов ${ }^{137} \mathrm{Cs}$ и

${ }^{90} \mathrm{Sr}$, достаточно продолжительное время их жизни $\left(\mathrm{T}_{1 / 2} \approx 30\right.$ лет) и возможное совместное присутствие долгоживущего изотопа ${ }^{135} \mathrm{Cs}\left(\mathrm{T}_{1 / 2}=2,3 \cdot 10^{6}\right.$ лет) делают целесообразным переработку ${ }^{137} \mathrm{Cs}\left({ }^{90} \mathrm{Sr}\right)$-содержащих отходов в соответствии с принципами, декларируемыми МАГАТЭ для обращения с долгоживущими ВАО.

Международная стратегия обращения с ВАО нацелена на их надежную долговременную изоляцию от биосферы посредством мультибарьерного захоронения в глубинных геологических хранилищах после перевода в устойчивую твердую форму [4]. Экологическая безопасность такого хранилища зависит от системы инженерных барьеров и обеспечивается соответствием физико-химических свойств отвержденного материала и вмещающих пород места захоронения. Исходя из этого, наиболее приемлемой формой для экологически безопасного захоронения радиоактивных отходов считаются материалы, подобные минералам вмещающих пород захоронения [5-7].

На территории России в качестве наиболее вероятного места локализации могильника ВАО рассматривается Нижнеканский гранитоидный массив, расположенный на правобережье p. Енисей северо-восточнее г. Красноярска [8]. Основными породообразующими минералами гранитоидных пород являются каркасные алюмосиликаты, такие как полевые шпаты и фельдшпатоиды, поэтому безопасное захоронение ${ }^{137} \mathrm{Cs}-$ и ${ }^{90} \mathrm{Sr}-$ содержащих ВАО в гранитоидном массиве следует проводить в алюмосиликатных матрицах твердых растворов полевых шпатов и фельдшпатоидов, в структуру которых на основе изоморфных замещений могут входить радионуклиды [7].

$$
-347-
$$


В последние годы для иммобилизации ${ }^{137} \mathrm{Cs}\left({ }^{90} \mathrm{Sr}\right)$-содержащих отходов в минералоподобной форме показана перспективность применения полых алюмосиликатных микросфер летучих энергетических зол (ценосфер [9]), образующихся из алюмосиликатного расплава минеральной части углей при их пылевидном сжигании [10-12] и фактически являющихся доступным возобновляемым алюмосиликатным сырьем с годовым объемом производства в России свыше 100 тыс. т [13].

Вместе с тем применимость ценосфер и материалов на их основе в качестве минералообразователей для иммобилизации ВАО и последующего захоронения минералоподобных продуктов на основе критерия геохимической совместимости в толще пород определенного типа, в данном случае гранитоидов, зависит от их состава, в частности от соотношения в исходном сырье таких макрокомпонентов, как оксиды кремния и алюминия. Очевидно, что этот параметр будет отличаться для ценосфер различного происхождения и разных способов разделения.

В этой связи представляет интерес провести сравнительный анализ составов ценосфер, полученных при сжигании различных углей на тепловых электростанциях России, составов магматических горных пород, слагающих площадки предполагаемого захоронения РАО, и основных породообразующих минералов этих пород как потенциальных алюмосиликатных матриц для фиксации $\mathrm{Cs}$ и $\mathrm{Sr}$ для выбора алюмосиликатного прекурсора конечной формы захоронения отходов, соответствующей гранитоидным породам и/или породообразующим минералам по химическому и фазовому составу.

Цель работы - продемонстрировать теоретическую и практическую возможность перевода ${ }^{137} \mathrm{Cs}(\mathrm{Na})$-содержащих ЖРО в прогнозируемые минералоподобные матрицы, геохимически совместимые с гранитоидами при долговременном захоронении, с использованием в качестве алюмосиликатного прекурсора ценосфер энергетических зол от сжигания углей Кузнецкого бассейна.

\section{Экспериментальная часть}

Получение и характеристика исходного материала ценосфер

В работе в качестве исходного материала использовали узкую фракцию перфорированных немагнитных ценосфер крупностью $-0,5+0,25$ мм, насыпной плотностью $(0,38 \pm 0,01)$ г/см удельной поверхностью $(0,41 \pm 0,03) \mathrm{M}^{2} / \Gamma$, которую выделили из концентрата ценосфер летучих зол от сжигания угля Кузнецкого бассейна (Россия) на Томь-Усинской ГРЭС согласно способу $[14,15]$. Общий вид и структура материала оболочки ценосфер по данным сканирующей электронной микроскопии представлены на рис. 1. Состав перфорированных ценосфер охарактеризован методами химического и рентгенофазового анализа. Химический состав выделенной фракции, мас. \%: $\mathrm{SiO}_{2} 66,36 ; \mathrm{Al}_{2} \mathrm{O}_{3} 19,60 ; \mathrm{Fe}_{2} \mathrm{O}_{3} 3,44 ; \mathrm{CaO} 2,74 ; \mathrm{MgO} 2,24 ; \mathrm{Na}_{2} \mathrm{O}$ 1,40; $\mathrm{K}_{2} \mathrm{O}$ 2,$90 ; \mathrm{TiO}_{2} 0,18 ; \mathrm{SO}_{3} 0.4 ;$ ппп 0,40; $\mathrm{SiO}_{2} / \mathrm{Al}_{2} \mathrm{O}_{3} 3,4$. По данным количественного рентгенофазового анализа содержание стеклофазы в данной фракции составляет 92,2 мас. \%, кварца 5,9 мас. \%, муллита 1,5 мас. \%, кальцита 0,4 мас. \%.

\section{Отверждение $\mathrm{Cs}(\mathrm{Na})$-содержащих растворов с использованием иеносфер}

Отверждение $\mathrm{Cs}(\mathrm{Na})-$ содержащих растворов для изучения фазового состава отвержденных продуктов проводили с использованием модельных азотнокислых растворов натрия и цезия

$$
-348-
$$



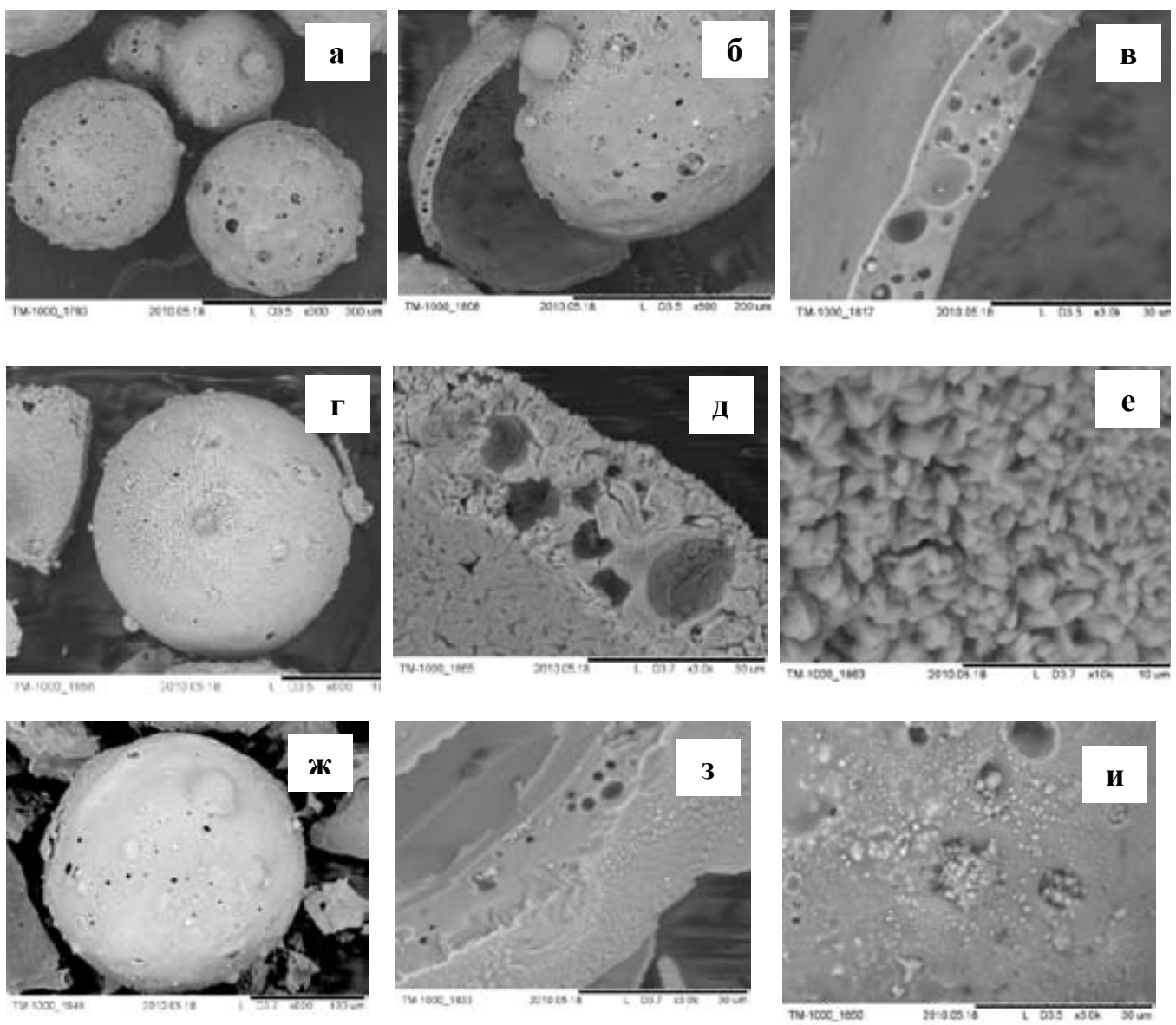

Рис. 1. Перфорированные ценосферы из летучих зол от сжигания кузнецких углей (а - общий вид; б - сломанная глобула; в - структура стенки на срезе) и микросферические продукты отверждения растворов нитратов цезия (г-е) и натрия (ж-и) (г, ж - общий вид; д, 3 - поперечный срез оболочки; е, и - участок поверхности)

как имитаторов радиоактивных ${ }^{137} \mathrm{Cs}$-содержащих растворов - высокосолевых регенератов, реэкстрата цезия или кубовых остатков АЭС. Для изучения химической устойчивости отвержденных компаундов методом длительного выщелачивания цезия отверждению подвергали реальные радиоактивные высокосолевые растворы от регенерации ионитов $\left(\mathrm{NaNO}_{3}\right.$ - около 100 г/л, ${ }^{137} \mathrm{Cs}-6,1 \times 10^{8}$ Бк/л) и раствор нитрата цезия с меткой ${ }^{137} \mathrm{Cs}$.

Отверждение проводили в режиме «смешивание ценосфер с раствором $\mathrm{NaNO}_{3} / \mathrm{CsNO}_{3}$ в заданном соотношении - сушка при температурах 80-120 ${ }^{\circ} \mathrm{C}$ - термообработка при выбранных температурах» как показано на схеме:

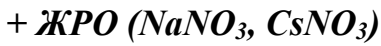

$T$

Ценосферы ---------- $\rightarrow$ ценосферно-солевая композиция

минералоподобный

пропитка, сушка

твердофазная

компаунд

\section{кристаллизация}


Количество $\mathrm{NaNO}_{3}\left(\mathrm{Na}_{2} \mathrm{O}\right) / \mathrm{CsNO}_{3}\left(\mathrm{Cs}_{2} \mathrm{O}\right)$ вводили с учетом имеющегося в ценосферах содержания алюминия $\left(\mathrm{Al}_{2} \mathrm{O}_{3}\right)$, ориентируясь на получение компаунда с максимально возможным содержанием нефелина/поллуцита для данного состава ценосфер.

\section{Методы исследования}

Химический состав фракции ценосфер определяли согласно ГОСТ 5382-91 [16].

Рентгенодифракционные спектры образцов записывали на дифрактометре X'Pert PRO MPD (PANalytical, Нидерланды) с твердотельным детектором PIXcel и вторичным графитовым монохроматором для $\mathrm{Cu} \mathrm{K}_{\alpha}$-излучения. Структуру и количественный фазовый состав исходных ценосфер и отвержденных продуктов определяли методом порошкового рентгенофазового анализа с использованием полнопрофильного формализма Ритвельда [17] с оптимизацией структурных параметров и фазовых концентраций методом минимизации производной разности [18].

Выбор температурного режима кристаллизации ценосферно-солевых композиций осуществляли, основываясь на данных синхронного термического анализа (CTA), который проводили на приборе STA 449C Jupiter с блоком QMS PulseTA (NETZSCH-GERATEBAU GMBH, Германия).

Электронно-микроскопические исследования образцов осуществляли с помощью электронного сканирующего микроскопа TM-1000 (Hitachi, Япония) с рентгеноспектральным энергодисперсионным анализатором SwiftED (Oxford Instrument Analytical, Англия) при регистрации в обратно рассеянных электронах с ускоряющим напряжением 15 кВ в режиме низкого вакуума без предварительного напыления проводящих покрытий на образцы. Отдельные участки пробы подвергались спектральному анализу.

Изучение химической устойчивости отвержденных отходов проводили определением скорости выщелачивания цезия при длительном контакте с дистиллированной водой согласно национальному стандарту РФ ГОСТ Р 52126-2003 [19].

Удельную площадь поверхности ценосфер (S) определяли методом БЭТ по стандартной методике исходя из данных по измерению изотерм адсорбции-десорбции азота при 77 К с использованием анализатора площади поверхности и размеров пор Nova 3200e (QUANTACHROME INSTRUMENTS, CШA).

\section{Результаты и обсуждение}

Использование отночения $\mathrm{SiO}_{2} / \mathrm{Al}_{2} \mathrm{O}_{3}$ как критерия

для выбора алюмосиликатного прекурсора устойчивых минеральных форм

на основе иеносфер для захоронения

в гранитоидах Нижнеканского гранитоидного массива

Ценосферы представляют собой мелкодисперсный сыпучий порошок, состоящий из полых частиц сферической формы диаметром 20-500 мкм с тонкой, толщиной 5-10 мкм, стеклокристаллической оболочкой на основе алюмосиликатного стекла (85-95 мас. \%) с включениями минорных количеств фаз кварца, муллита и железистой шпинели, т.е. являются метастабильными системами, способными трансформироваться со временем в цеолиты, смектиты или галлуазиты в результате выветривания [20] и под действием гидротермальной обработки [21]. 
Благодаря более высокой однородности по сравнению с другими компонентами летучих зол и возможности дополнительной стабилизации состава микросфер за счет различий физических параметров гранул (плотности, размера, магнитных свойств, морфологии) [22] именно этот вид отходов позволяет получать прогнозируемые минералоподобные формы отверждения ЖРО на основе фаз каркасных алюмосиликатов (полевые шпаты, фельдшпатоиды) исходя из продуктов их химической модификации - микросферических цеолитов и блочных пористых материалов [10-12].

При создании процессов отверждения ЖРО с использованием ценосфер для захоронения в гранитоидах Нижнеканского гранитоидного массива следует также ориентироваться на сырье, наиболее приближенное к местам захоронения. Таким сырьем могут являться ценосферы, образующиеся в результате сжигания углей Кузнецкого бассейна в регионах Западной Сибири, в частности в Кемеровской области (Томь-Усинская ГРЭС, г. Мыски; Беловская ГРЭС, г. Белово), а также в Новосибирской области (Новосибирская ТЭЦ-5, г. Новосибирск). Кузнецкие угли характеризуются наиболее высоким выходом ценосфер в результате их сжигания (>1 \%), причем при прогнозируемом повышении потребления в России кузнецких углей в ближайшее десятилетие ожидается увеличение образования ценосфер в 2-2,5 раза [23].

Одним из критериев применимости ценосфер в качестве алюмосиликатного прекурсора минералоподобных форм фиксации радионуклидов цезия и стронция является величина отношения $\mathrm{SiO}_{2} / \mathrm{Al}_{2} \mathrm{O}_{3}$, которая, в свою очередь, есть геохимический индикатор минеральных форм угля, ответственных за образование ценосфер. Основными минералами-предшественниками ценосфер служат глинистые минералы - каолинит, иллит и монтмориллонит $\left(\mathrm{SiO}_{2} / \mathrm{Al}_{2} \mathrm{O}_{\text {3мас. }}\right.$ 1,$2 ; 1,4$ и 2,8 соответственно) [24], которые в сочетании с кварцем образуют расплав с определенной вязкостью, что приводит к формированию ценосфер различного диаметра, толщины и пористости в указанном интервале составов. Отношение $\mathrm{SiO}_{2} / \mathrm{Al}_{2} \mathrm{O}_{3}$ может быть прогнозным параметром при выборе сырья для отверждения ЖРО, в частности для определения концентратов ценосфер, в которых содержание узких фракций ценосфер заданного состава будет максимальным.

Исходя из критерия фазово-химического соответствия формы отверждения вмещающим породам [7] интерес представляют такие ценосферы, которые максимально соответствуют по составу как породам, слагающим горный массив площадки захоронения, так и породообразующим минералам, выбранным в качестве кристаллической матрицы для захоронения в данном массиве.

Сравнительный анализ составов ценосфер показал, что для зарубежных источников (Великобритания, США, Китай, Испания, Индия, Корея, Южная Африка, Австралия, Казахстан) диапазон отношений $\mathrm{SiO}_{2} / \mathrm{Al}_{2} \mathrm{O}_{3}$ находится в интервале $1,2-2,4[23,5,26]$. В свою очередь, для концентратов ценосфер от сжигания кузнецких углей (Новосибирская ТЭЦ-5, Томь-Усинская ГРЭС, Владимирская ТЭЦ-1, Беловская ГРЭС) характерно отношение $\mathrm{SiO}_{2} / \mathrm{Al}_{2} \mathrm{O}_{3}$ 3-3,5. Эту же область перекрывают и магматические породы, слагающие площадку предполагаемого захоронения РАО Нижнеканского гранитоидного массива, который состоит из двух петрографических ассоциаций магматических пород. Первая ассоциация объединяет кварцевые диориты, гранодиориты, низкощелочные граниты, граниты и лейкограниты, а вторая - сиениты, кварце- 
вые сиениты, субщелочные граниты и лейкограниты [8]. Отношение $\mathrm{SiO}_{2} / \mathrm{Al}_{2} \mathrm{O}_{3}$ в этих породах находится в интервале 2,6-3,8.

Таким образом, концентраты ценосфер из летучих зол от сжигания кузнецких углей по своему алюмосиликатному модулю соответствуют большинству среднекислых магматических пород $\left(\mathrm{SiO}_{2} / \mathrm{Al}_{2} \mathrm{O}_{3}=3 \pm 0,8\right)$ [27], а с учетом невысокого содержания железа (4-5 мас. \% $\left.\mathrm{Fe}_{2} \mathrm{O}_{3}\right)$ наиболее близки к гранитоидам.

Для получения продуктов отверждения, близких к мономинеральным материалам, целесообразно использовать ценосферы с близким к выбранным минералам отношением $\mathrm{SiO}_{2} / \mathrm{Al}_{2} \mathrm{O}_{3}$ и минимальным содержанием балластных компонентов, например железа. Известные способы разделения концентратов ценосфер $[14,22]$ позволяют отделять ценосферы от загрязняющих примесей и выделять узкие фракции ценосфер, различающиеся по составу, морфологии и свойствам. Показано, что при разделении концентратов ценосфер от сжигания кузнецких углей возможно получение узких фракций в диапазоне отношений $\mathrm{SiO}_{2} / \mathrm{Al}_{2} \mathrm{O}_{3}=1,2-3,5$ с содержанием железа менее 4 мас. \% в расчете на $\mathrm{Fe}_{2} \mathrm{O}_{3}[15,28]$.

На рис. 2 нанесены составы таких породообразующих минералов (полевых шпатов и фельдшпатоидов), а также цеолитов, слюд и глин, которые могут развиваться по породообразующим минералам в результате метаморфических и других послемагматических процессов. Соотношение основных каркасообразующих оксидов $\mathrm{SiO}_{2}$ и $\mathrm{Al}_{2} \mathrm{O}_{3}$ в этих минералах также находится в интервале 1,2-3,5.

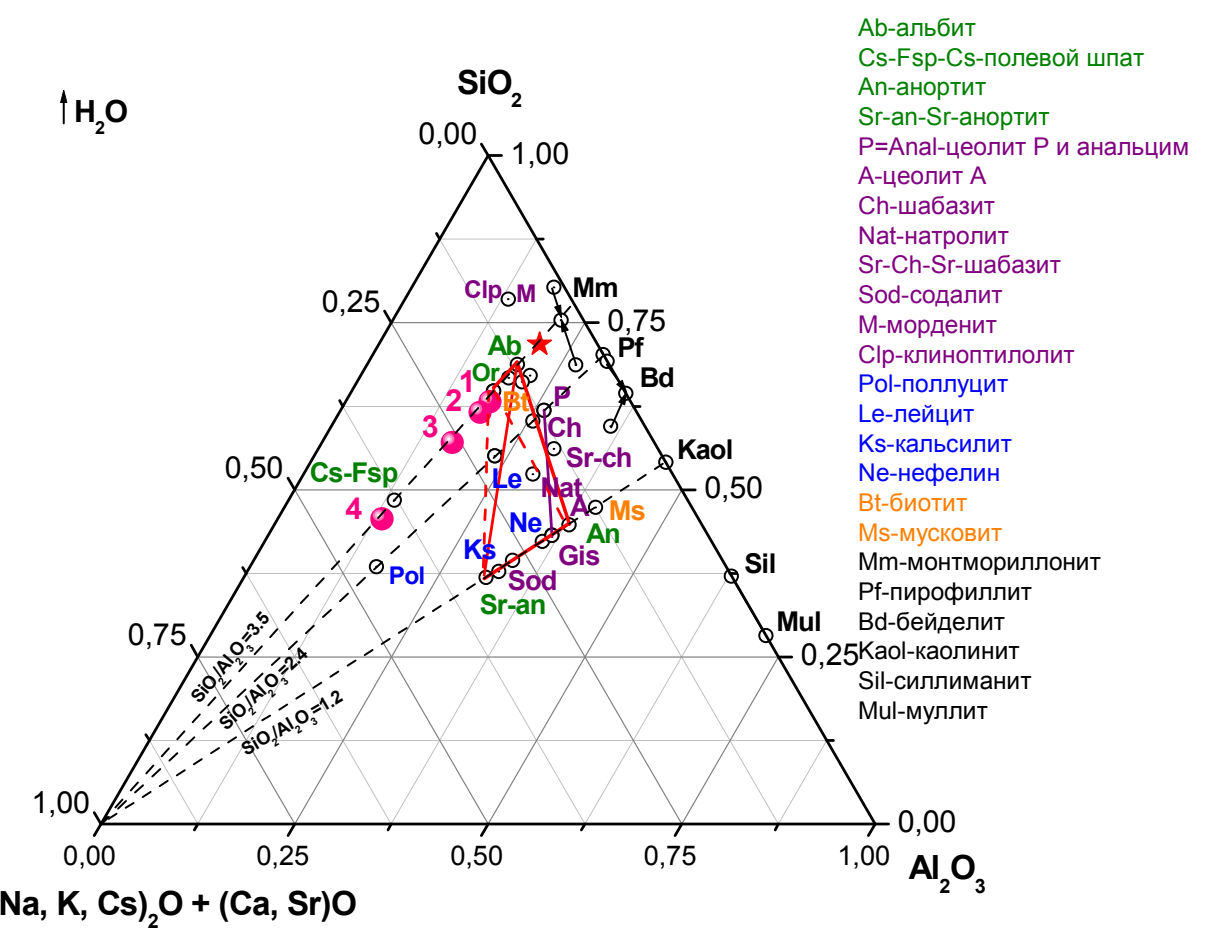

Рис. 2. Составы минералов (открытые кружки), ценосфер Томь-Усинской ГРЭС (звездочка) и компаундов на основе ценосфер (цифры 1-4). Сплошными линиями показаны твердые растворы между полевыми шпатами 
Можно ожидать, что при добавлении стехиометрического количества оксидов натрия, цезия и/или стронция к ценосферам состава гранитоидных пород $\left(\mathrm{SiO}_{2} / \mathrm{Al}_{2} \mathrm{O}_{3}=3-3,5\right)$ существует теоретическая возможность получения твердых растворов минералов с таким же и/или с меньшим соотношением $\mathrm{SiO}_{2} / \mathrm{Al}_{2} \mathrm{O}_{3}$, а именно $\mathrm{Na}$, K,Cs-, $\mathrm{Na}(\mathrm{Ca}) \mathrm{Sr}$-полевых шпатов и/или фельдшпатоидов $\left(\mathrm{SiO}_{2} / \mathrm{Al}_{2} \mathrm{O}_{3}=3,5-1,2\right)$, которые способны изоморфно включать радиоизотопы ${ }^{137} \mathrm{Cs}$ и ${ }^{90} \mathrm{Sr}$. Для отверждения модельных азотнокислых растворов натрия и цезия как имитаторов радиоактивных ${ }^{137} \mathrm{C}$-содержащих растворов - высокосолевых регенератов, реэкстрата цезия или кубовых остатков АЭС - наиболее привлекательными минералами являются фельдшпатоиды поллуцит и нефелин $\left(\mathrm{SiO}_{2} / \mathrm{Al}_{2} \mathrm{O}_{3}=2,4\right.$ и 1,2 соответственно), инкорпорирующие цезий. В этом случае избыточный $\mathrm{SiO}_{2}$ (при образовании минералов с меньшим модулем) будет оставаться в виде свободного кварца и/или в стеклофазе.

Следует отметить, что при долговременном захоронении в случае проникновения грунтовых вод к минералоподобным матрицам со структурами полевых шпатов и фельдшпатоидов с течением длительного времени могут происходить трансформации этих структур в глинистые или слюдоподобные материалы, которые обладают сорбирующей и удерживающей способностью в отношении ионов цезия и стронция, что будет препятствовать миграции радионуклидов и, следовательно, не будет нарушаться безопасность захоронения.

Таким образом, проведенный анализ показал, что ценосферы от сжигания кузнецких углей по соотношению $\mathrm{SiO}_{2} / \mathrm{Al}_{2} \mathrm{O}_{3}$ при введении оксидов щелочных и щелочно-земельных элементов могут являться алюмосиликатными прекурсорами минералоподобных материалов, соответствующих по химическому составу как породам гранитоидов, так и породообразующим алюмосиликатным минералам этих пород.

\section{Отверждение Cs- u Na-содержащих растворов}

с использованием перфорированных иеносфер $\left(\mathrm{SiO}_{2} / \mathrm{Al}_{2} \mathrm{O}_{3}=3,4\right)$

На рис. 3 приведены кривые дифференциальной сканирующей калориметрии (ДСК) для ценосферно-солевых композиций с нитратами натрия и цезия $\left(\mathrm{Na}_{2} \mathrm{O}=19 \%\right.$ и $\mathrm{Cs}_{2} \mathrm{O}=35 \%$ соответственно). На термограммах ценосферно-солевых композиций с разным количеством введенного нитрата натрия $\left(8,12\right.$ и 19 мас. \% $\left.\mathrm{Na}_{2} \mathrm{O}\right)$ наблюдаются три резких эндотермических эффекта: первые два - при 273-273,4 и 305-306,8 ${ }^{\circ} \mathrm{C}$ - связаны с плавлением нитрита и нитрата натрия соответственно; третий - при температуре $653-675,6{ }^{\circ} \mathrm{C}$, начиная с $400{ }^{\circ} \mathrm{C}$ вплоть до $650-700{ }^{\circ} \mathrm{C}$, обусловлен термическим разложением расплава нитрата натрия. Одновременно происходит химическое взаимодействие его расплава с аморфным алюмосиликатным материалом ценосфер с образованием $\mathrm{NaAlSiO}_{4}$ (карнегиит и нефелин) (экзотермический эффект при 670-720 을. При этом, по данным РФА, карнегиит образуется уже при температуре $700{ }^{\circ} \mathrm{C}$ в течение 30 минут и, являясь метастабильной модификацией, при дальнейшем увеличении времени выдержки и/или температуры трансформируется в нефелин [11].

На термограмме ценосферно-солевой композиции с нитратом цезия также наблюдаются три эндотермических эффекта: первый, при температуре $154,7{ }^{\circ} \mathrm{C}$, связан с полиморфным гексагонально-кубическим переходом в нитрате цезия; второй, при 405,3 ${ }^{\circ} \mathrm{C}$, связан с плавлением нитрата цезия. Практически одновременно с плавлением начинается разло- 
жение нитрата цезия, которое заканчивается при $778{ }^{\circ} \mathrm{C}$. Согласно данным РФА уже при температуре $700{ }^{\circ} \mathrm{C}$ происходит образование поллуцита. Начиная с $850{ }^{\circ} \mathrm{C}$ наблюдается незначительное уменьшение массы, возможно, за счет улетучивания оксида цезия $(0,39 \%)$. Экзоэффект при $970{ }^{\circ} \mathrm{C}$ может быть связан с переходом образующихся при малом времени выдержки низкотемпературных фаз алюмосиликатов цезия (CsAlSiO${ }_{4}$ и/или $\left.\mathrm{CsAlSi}_{5} \mathrm{O}_{12}\right)$ в поллуцит [29]. На основании результатов синхронного термического анализа для получения целевых алюмосиликатных фаз на основе ценосферно-солевых композиций с нитратами натрия и цезия, а именно нефелина и поллуцита, были выбраны температуры 750 и $1100{ }^{\circ} \mathrm{C}$, соответственно.

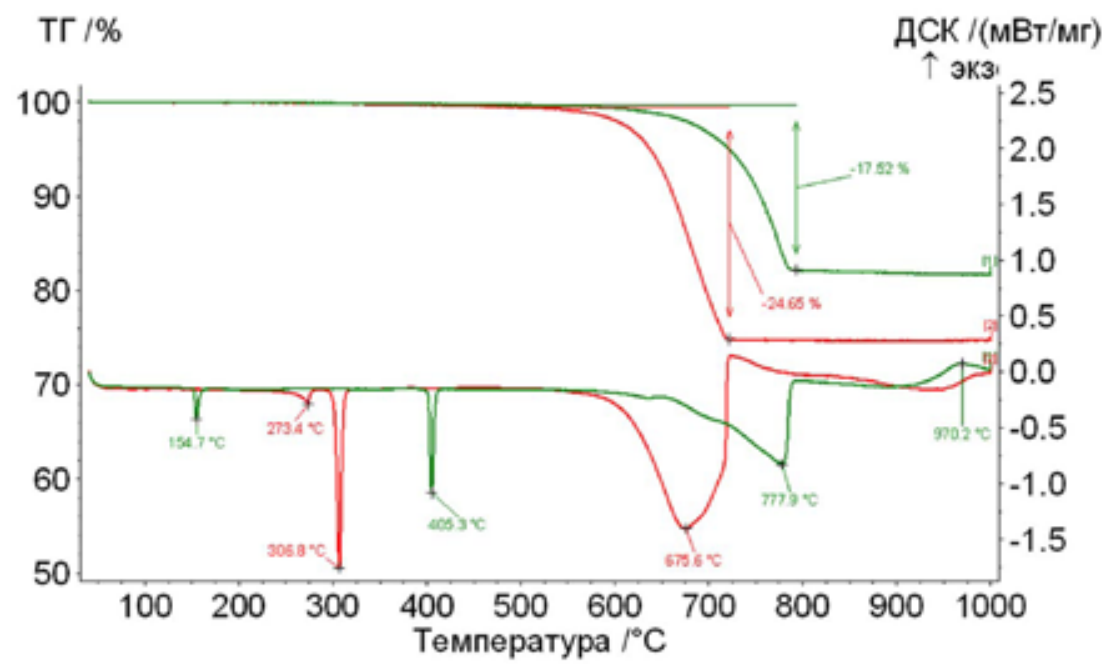

Рис. 3. Кривые ДСК ценосферно-солевых композиций с $\mathrm{NaNO}_{3}\left(\mathrm{Na}_{2} \mathrm{O}=19\right.$ \%, красным цветом) и $\mathrm{CsNO}_{3}$ $\left(\mathrm{Cs}_{2} \mathrm{O}=35 \%\right.$, зеленым цветом)

Таблица. Условия отверждения и фазовый отвержденных компаундов с использованием ценосфер

\begin{tabular}{|c|c|c|c|c|c|c|c|c|c|c|c|}
\hline \multicolumn{12}{|l|}{ Условия отверждения } \\
\hline Температура, ${ }^{\circ} \mathrm{C}$ & 750 & 750 & 1000 & 750 & 750 & 1000 & 1000 & 750 & 1100 & 750 & 1100 \\
\hline Длительность, ч & 3 & 24 & 3 & 3 & 24 & 3 & 3 & 24 & 3 & 24 & 3 \\
\hline Содержание $\mathrm{Na}_{2} \mathrm{O}, \%$ & 8 & 8 & 8 & 12 & 12 & 12 & 19 & 19 & 19 & - & - \\
\hline Содержание $\mathrm{Cs}_{2} \mathrm{O}, \%$ & - & - & - & - & - & - & - & - & - & 35 & 35 \\
\hline \multicolumn{12}{|c|}{ Фазы, идентифицированные по РФА, \% } \\
\hline Стеклофаза & 85,4 & 79,4 & 84 & 79,3 & 69,5 & 97,4 & 95,1 & 61,3 & 97,9 & 44,3 & 18,3 \\
\hline Нефелин, $\mathrm{NaAlSiO}_{4}$ & 10,2 & 16,2 & 7,6 & 17,5 & 26,8 & 1,0 & 2,7 & 37,0 & 0,5 & - & - \\
\hline Поллуцит, $\mathrm{CsAlSi}_{2} \mathrm{O}_{6}$ & - & - & - & - & - & - & - & - & - & 52,9 & 79,1 \\
\hline Кварц, $\mathrm{SiO}_{2}$ & 3,2 & 2,8 & 2,7 & 3,2 & 3,4 & 1,6 & 1,1 & 1,7 & 1,6 & 1,0 & 1,9 \\
\hline Муллит, $\mathrm{Al}_{6} \mathrm{Si}_{2} \mathrm{O}_{13}$ & 1,2 & 1,0 & - & - & - & - & - & - & - & - & - \\
\hline Диопсид, $\mathrm{CaMgSi}_{2} \mathrm{O}_{6}$ & - & - & 5,7 & - & - & - & 1,1 & - & - & - & - \\
\hline Гематит, $\mathrm{Fe}_{2} \mathrm{O}_{3}$ & - & 0,6 & 0,7 & - & 0,3 & - & - & - & - & 1,8 & 0,7 \\
\hline
\end{tabular}


Фазовые составы полученных при выбранных температурах компаундов представлены в таблице. Составы этих же образцов нанесены на рис. 2. Для ценосферно-солевых композиций с 8 и 12 мас. \% $\mathrm{Na}_{2} \mathrm{O}$ (точки 1 и 2 на рис. 2) увеличение времени выдержки при $750{ }^{\circ} \mathrm{C} \mathrm{c}$ 3 до 24 ч приводит к возрастанию фазы нефелина в компаунде в 1,3-1,5 раза. Максимальное количество нефелина (37 мас. \%) получено для компаундов с содержанием $\mathrm{Na}_{2} \mathrm{O} 19$ мас. \% (точка 3 на рис. 2), что превышает теоретически требуемое для связывания в нефелине всего алюминия, имеющегося в ценосферах $\left(\mathrm{Na}_{2} \mathrm{O}=12,5\right.$ мас. \%). Повышение температуры обработки до 1000-1100 ㄷ для ценосферно-солевой композиции, содержащей 19 мас. \% $\mathrm{Na}_{2} \mathrm{O}$, приводит к образованию прозрачного однородного монолитного компаунда, состоящего преимущественно из стеклофазы (>97 мас. \%), и минорных количеств кварца (1,6 мас. \%) и нефелина (0,5-1 мас. \%). Термообработка ценосферно-солевых композиций с $\mathrm{Cs}_{2} \mathrm{O}=35$ мас. \% (точка 4 на рис. 2) привела к преимущественному образованию прогнозируемой фазы поллуцита 53 и 79 мас. \%. Повышение температуры с 750 до 1100 C вызвало возрастание фазы поллуцита в 1,5 раза.

Таким образом, на основании данных количественного рентгенофазового анализа установлено, что отверждение по предложенной схеме $\mathrm{Na}-$ и $\mathrm{Cs}-$ содержащих растворов с использованием ценосфер с $\mathrm{SiO}_{2} / \mathrm{Al}_{2} \mathrm{O}_{3}=3,4$ позволяет получить при выбранных температурах стеклокристаллические компаунды, включающие прогнозируемые фазы нефелина (до 37 мас. \%) и поллуцита (до 79 мас. \%) с отношением $\mathrm{SiO}_{2} / \mathrm{Al}_{2} \mathrm{O}_{3}=1,2$, и 2,4 соответственно. Избыточный $\mathrm{SiO}_{2}$ входит в стеклофазу, содержание которой больше в компаундах с нефелином ( 70 мас. \%), чем с поллуцитом (18 мас. \%).

Полученные данные подтверждаются результатами сканирующей электронной микроскопии продуктов отверждения (рис. 1,4$)$, свидетельствующими о более полной раскристаллизации Cs-содержащей ценосферно-солевой композиции (рис. 1 2-e) по сравнению с Na-содержащей системой (рис. $1 \nsim-u$ ). На рис. 4 видно, что натрий и цезий входят в состав соответствующих продуктов отверждения во вновь образованные кристаллические фазы нефелина и поллуцита соответственно. Полученный стеклокристаллический материал с введенным радионуклидом ${ }^{137} \mathrm{Cs}$ характеризуется низкой скоростью выщелачивания цезия $-5,3 \cdot 10^{-9}$ и $2,3 \cdot 10^{-8} \Gamma / \mathrm{cm}^{2} \times \mathrm{cyт}$ (21 сут, $\left.(25 \pm 3){ }^{\circ} \mathrm{C}\right)$, что на 2-3 порядка ниже, чем установлено российскими требованиями к отвержденным высокоактивным отходам $\left(\geq 1 \cdot 10^{-6} \Gamma / \mathrm{cm}^{2} \cdot\right.$ сут) [30].

Таким образом, с использованием алюмосиликатного сырья, а именно немагнитных перфорированных ценосфер летучих зол от сжигания кузнецких углей с отношением $\mathrm{SiO}_{2} / \mathrm{Al}_{2} \mathrm{O}_{3}$, приближенного к Нижнеканскому гранитоидному массиву как месту предполагаемого захоронения ВАО, получены химически устойчивые минералоподобные формы иммобилизации ${ }^{137} \mathrm{Cs}(\mathrm{Na})$-содержащих растворов с включением радионуклида ${ }^{137} \mathrm{Cs}$ в кристаллическую фазу поллуцита. Ожидается, что отвержденные компаунды, отвечая критериям физико-химического соответствия вмещающим породам, будут находиться в геохимическом равновесии и тем самым обеспечивать экологическую безопасность системы геологического захоронения радиоактивных отходов.

Авторы выражают благодарность сотрудникам ИХХТ СО РАН Л.А. Соловьеву за проведение количественного рентгенофазового анализа, С.Н. Верещагину за проведение синхронного термического анализа, А.М. Жижаеву за съемку образцов на сканирующем электронном ми- 

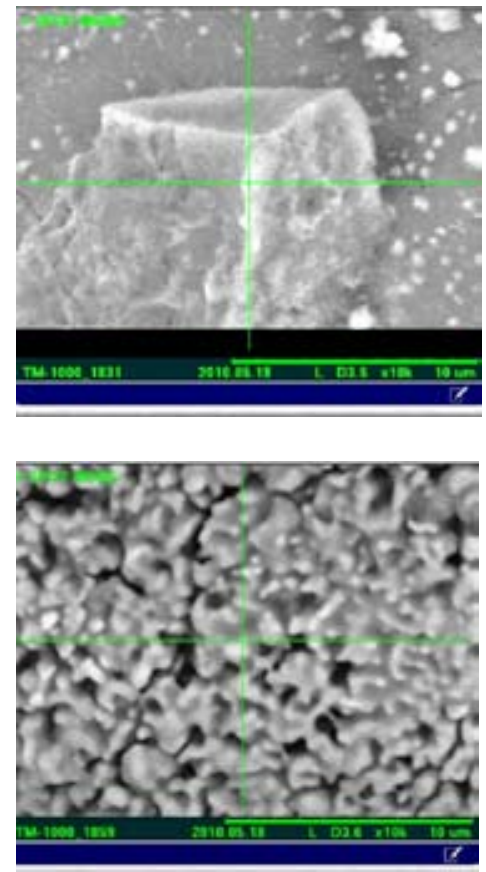
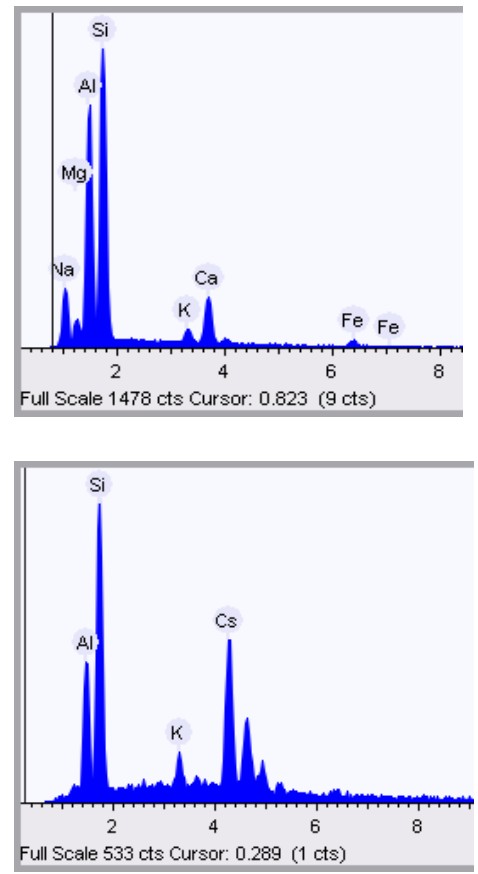

Рис. 4. Элементный состав поверхности материалов (по данным энергодисперсионного спектрального анализа), содержащих нефелин (верхний ряд) и поллуцит (нижний ряд). Увеличение 10000

кроскопе, В.В. Юмашеву за определение удельной поверхности ценосфер, а также сотрудникам Горно-химического комбината ГК «Росатом» РФ (г. Железногорск, Красноярский край) за получение отвержденных компаундов с введенным ${ }^{137} \mathrm{Cs}$ и определение скорости выщелачивания цезия.

\section{Список литературы}

1. Classification of Radioactive Waste. Safety Series No.111-G-1.1. Vienna: IAEA, 1994.

2. Дмитриев С.А., Баринов. А.С., Батюхнова О.Г., Волков А.С., Ожован М.И., Щербатова Т.Д. Технологические основы системы управления радиоактивными отходами. Москва: ГУП МосНПО Радон, 2007. 376 с. [Dmitriev C.A., Barinov A.C., Batukhnova O.G., Volkov A.C., Ojovan M.I., Shcherbatova T.D. Technological basis of radioactive waste management. Moscow: GUP MosNPO Radon, 2007. 376 p. (In Russ.)].

3. Brumfiel G., Cyranoski D. Fukushima deep in hot water // Nature. 2011. Vol. 474. P. 135136.

4. ElBaradei M. Geological Repositories: The Last Nuclear Frontier. International Conference on Geological Repositories, 8-10 December 2003, Stockholm, Sweden; Radioactive waste management: an IAEA source book, Vienna: IAEA, 1992.

5. Hatch L.P. Ultimate Disposal of Radioactive Waste // American Scientist. 1953. 41. P. 410-421.

6. Laverov N.P., Yudintsev S.V., Stefanovsky S.V., Omel'yanenko B.I., Nikonov B.S. Murataite as a universal matrix for immobilization of actinides // Geology of Ore Deposits. 2006. Vol. 48. P. $335-356$. 
7. Котельников А.Р., Ахмеджанова Г.М., Суворова В.А. Минералы и их твердые растворыматрицы для иммобилизации радиоактивных отходов // Геохимия. 1999. Т. 38(2). С. 192-199. [Kotel'nikov A.R., Akhmedjanova G.M., Suvorova V.A. Minerals and its solid solutions - matrices for immobilization of radioactive waste. Geochemistry 1999. Vol. 38(2). P. 192-199. (In Russ.)].

8. Белов С.В., Морозов В.Н., Татаринов В.Н., Камнев Е.Н., Хаммер Й. Изучение строения и геодинамической эволюции Нижнеканского массива в связи с захоронением высокоактивных радиоактивных отходов // Геоэкология. 2007. № 3. C. 248-266. [Belov S.V., Morosov V.N., Tatarinov V.N., Kamnev E.N., Hammer I. Study of structure and geodynamic evolution of Nizhnekanskii massif in connection with disposal of high level radioactive waste. Geoecology 2007. No. 3. P. 248-266 (In Russ.)].

9. Raask E. Cenospheres in pulverized-fuel ash // Journal of the Institute of Fuel. 1968. Vol. 41. P. 339-344.

10. Anshits N.N., Salanov A.N., Vereshchagina T.A., Kruchek D.M., Bajukov O.A., Tretyakov A.A., Revenko Yu.A., Anshits A.G. Composition, morphology, properties of coal fly ash microspheres and their application for conditioning liquid radioactive waste // International Journal of Nuclear Energy Science and Technology. 2006. Vol. 2(1-2), P. 8-24.

11. Vasil’eva N.G., Anshits N.N., Sharonova O.M., Burdin M.V., Anshits A.G. Immobilization of cesium and strontium radionuclides in framework aluminosilicates with the use of porous glasscrystalline matrices based on coal fly ash cenospheres // Glass Physics and Chemistry. 2005. Vol. 31(5). P. 637-647.

12. Vereshchagina T.A., Anshits N.N., Sharonova O.M., Vasil'eva N.G., Vereshchagin S.N., Shishkina N.N., Fomenko E.V., Anshits A.G. Polyfunctional microspherical materials for longterm disposal of liquid radioactive wastes // Glass Physics and Chemistry. 2008. Vol. 34(5). P. 547-558.

13. Кизильштейн Л.Я., Дубов И.В., Шпицглуз А.Л., Парада С.Г. Компоненты зол и шлаков ТЭС. М.: Энергоатомиздат, 1995. 176 c. [Kizil'shtein L.Ya., Dubov I.V., Shpitsgluz A.L., Parada S.G. Components of ashes and slags of heat power plants; Moscow: Energoatomizdat, 1995. 176 p. (In Russ.)].

14. Патент 2212276 РФ. Аншиц А.Г., Левинский А.И., Верещагин С.Н., Подойницын С.В. Способ разделения ценосфер летучих зол тепловых электростанций. Опубл. 10.05.2003. [Patent 2212276 RU. Anshits A.G., Levinskii A.I., Vereshchagin S.N., Podoinitsyn S.V. Method for separation of fly ashes of power plants. Publ. Date 10.05.2003 (In Russ.)].

15. Anshits N.N., Mikhailova O.A., Salanov A.N., Anshits A.G. Chemical composition and structure of the shell of fly ash non-perforated cenospheres produced from the combustion of the Kuznetsk coal (Russia) // Fuel. 2010. Vol. 89(8). P. 1849-1862.

16. ГОСТ 5382-91 «Цементы и материалы цементного производства. Методы химического анализа». М.: ИПК издательство стандартов, 1991 [GOST 5382-91. Cements and materials for cement production. Chemical analysis methods. Moscow: IPK Izdatelstvo standartov, 1991 (In Russ.)].

17. Reitveld H. A profile refinement method for nuclear and magnetic structures // Journal of Applied Crystallography. 1969. Vol. 2. P. 65-71.

18. Solovyov L.A. Full-profile refinement by derivative difference minimization // Journal of Applied Crystallography. 2004. Vol. 37. P. 743-749.

$$
-357-
$$


19. ГОСТ Р 52126-2003. Отходы радиоактивные. Определение химической устойчивости отвержденных отходов методом длительного выщелачивания. М.: ИПК Издательство стандартов, 2003 [GOST R-52126-2003. Radioactive waste. Long time leach testing of solidified waste forms Moscow: IPK Izdatelstvo standartov, 2003 (In Russ.)].

20. Zevenbergen C., Bradley J.P., Van Reeuwijk L.P., Shyam A.K., Hjelmar O., Comans R.N.J. Clay formation and metal fixation during weathering of coal fly ash // Environmental Science and Technology 1999. Vol. 33. P. 3405-3409.

21. Vereshchagin S.N., Vereshchagina T.A., Shishkina N.N., Salanov A.N., Anshits A.G. Obtaining microspheric zeolites from vitrocrystalline cenospheres of power engineering ashes // Chemistry for Sustainable Development. 2008. Vol. 16(5). P. 519-527.

22. Патент 2328347 РФ. Аншиц А.Г., Левинский А.И., Верещагин С.Н. Способ разделения ценосфер летучих зол тепловых электростанций. Опубл. 10.07.2008 [Anshits A.G., Levinskii A.I., Vereshchagin S.N. Method for separation of fly ashes of power plants. Publ. Date 10.07.2008 (In Russ.)].

23. Рынок алюмосиликатных микросфер. ID отчета: MR-58090218. [Market of aluminosilicate microspheres. Report ID: MR-58090218 (In Russ.)] http://www.research-techart.ru

24. Шпирт М.Я. Безотходная технология. Утилизация отходов добычи и переработки твердых горючих ископаемых. М.: Недра, 1986. 255 с. [Shpirt M.Ya. Waste-free technology. Utilization of wastes from mining and processing solid combustible fossil. Moscow: Nauka, 1986. 255 p. (In Russ.)]

25. Ngu L., Wu H., Zhang D. Characterization of Ash Cenospheres in Fly Ash from Australian Power Stations // Energy and Fuels. 2007. Vol. 21(6). P. 3437-3445.

26. Moreno N., Querol X., Andres J. M., Stanton K., Towler M., Nugteren H., Janssen-Jurkovicová M., Jones R. Physicochemical characteristics of European pulverized coal combustion fly ashes // Fuel. 2005. Vol. 84. P. 1351-1363.

27. Ефремова С.В., Стафеев К.Г. Петрохимические методы исследования горных пород. М.: Недра, 1985. 511 c. [Efremova C.V., Stafeev K.G. Petrochemical methods to study rocks. Moscow: Nauka, 1985. 511 p. (In Russ.)]

28. Vasilieva N.G., Vereshchagina T.A., Anshits N.N., Vereshchagin S.N., Shishkina N.N., Solovyev L.A., Anshits A.G. Microspheric aluminosilicate sorbents for solidification of liquid radioactive wastes in the mineral-like form // Chemistry for Sustainable Development. 2010. Vol. 18(3). P. 231-237.

29. Vasilieva N.G., Strelnikov A.V., Aloy A.S., Anshits A.G. Cesium immobilization in framework aluminosilicates using porous glass ceramic matrices based on cenospheres of power plant fly ashes // In Proceeding of the VII International Conference "Safety of Nuclear Technologies: Radioactive Waste Management"; Saint-Petersburg: Pro Atom. 2004. P. 115-117.

30. ГОСТ Р 52126-2003. Отходы высокоактивные отвержденные. Общие технические требования. М.: ИПК Издательство стандартов, 2003. [GOST R 52126-2003. High level solidified waste. General technical requirements. Moscow: IPK Izdatelstvo standartov, 2003. (In Russ.)]. 